\title{
History of Buol: Study on The Border Territory and Exploitation of Mine
}

\author{
L. Nadjamuddin \\ History Education Study Program Universitas Tadulako \\ Palu, INDONESIA \\ lukmannadjamuddin@yahoo.com
}

\begin{abstract}
Study of Buol's history is very limited, particularly with regard to the border territory and the exploitation of mines. If this fact persists continuously, there will be discontinuities information between the reality in the past with the present reality. The research aims to clarify the position of Buol as the border territory between Central Sulawesi and Gorontalo also the exploitation of mines in Buol during the reign of the Dutch East Indies. The methodology used is Anthony Giddens structuration, which states that the structure consists of several components, namely the agent, which can make changes to the structure when it undergoes agency. Through the creation of the agent which is sustained by power and capability also through the interaction process continually. It is concluded that Buol is the agent of structure that is applied predominantly by Gorontalo and the colonial regime. Reaction and enforcement role in elite and Buol's community failed against the external structure, so that the control of the colonial regime in political life and the economy getting stronger. By the strength of capital and power, gold and mineral wealth exploited and Buol was forced to enter to the new structure that created by the colonial government.
\end{abstract}

Keywords: Buol; border territory; exploitation of mine.

\section{INTRODUCTION}

This research seeks the explanation about Buol's position located on a north tip of Central Sulawesi geographically. This region has a direct border to Gorontalo, a social group and a kingdom under Buol's influence in the colonial era. Gorontalo's effort to intervene must be seen as a colonial "invisible hand" behind their cultural closeness, between Gorontalo and Buol. The intervention was aimed to control all gold mines there.

It is unthinkable that Gorontalo's culture was a dominant character in economic and political dynamics of Buol. However, in Buol's history, Gorontalo had ever sent her high nobleman as king of Buol. Recently, there were three bwulyans who had a right of Buol's throne, namely: Bwulyan Pogogul, Bwulyan Kaili, and Bwulyan Mangindano. It is assumed that Gorontalo had a hegemonic power. This article is a result of research in the region of Buol Regency. To explain her historiography in a reconstruction context, a methodology is a necessary in guiding for factual analysis and making an objective conclusion.
The methodology here is structuration of Anthony Giddens. Giddens expresses that a structure consists of some components called as agent. In a structural paradigm with the structure as a dominant component, Giddens says that an agent can make a change toward structure as agent experiences at dynamicization (agency). By its creativity, supported by power and capability, and through a continuous interaction process that, enabled by structure, agent changes a such structure and creates a new one (reproduction). [1] Buol was an agent in a structure dominated by Gorontalo and colonial hegemony. Gold mine was a power for Buol to strengthen her position. However, gold as a basic capital could not function well as Buol's elite or common people could not manage it and change it into a pillar for the new structure.

To explain further on Buol as a border area with her gold mine, there are two problems, namely relation between Buol and Gorontalo, and colonial exploitation with Buol's resistance as a result. Both are a historical problem with political background. A fact behind it was the obscurity of central of power in Buol that motivated colonial power to control. Moreover, Buol's noble class was not derived from one offspring. Since Dainbolre or Bataralangit $( \pm 1540-1560)$ - son of King Punu Bwulyaan I (1430-1476) - there was agreed that there were two dynasties controlling Buol, namely dynasty of Pogogul (Buol) and the dynasty of Gua Monial (Kaili Sigi). [2] For annexing Buol, the Dutch used Gorontalo and Limboto kingdoms. Both kingdoms pressured Buol by their weapon. Pacification over Buol was too easy for the Dutch, dislike other regions in Central Sulawesi with their armed resistances and social movements. Gorontalo wanted that Buol was a part of him, but the Dutch did not allow because of Buol's gold mine.

The above explanation establishes, and in the same time questions Buol's political position toward Gorontalo as a colonial's hand. Therefore, Buol was one of border areas with her great potential natural source. Gold was a source of economic and social power for the colonial ruler after the spices in Moluccas islands and plantation industry in Java and Sumatra. 


\section{BuOl as a Part of Gorontalo's Cultural Area}

Buol had an autonomous governmental system. In legend, first king of Buol had two sons: Rodoali and Salvador, that changes his name to be Fernando after converting into Christian. [3] Another legend said that Buol was attacked by Kaili from Palu valley. [4] Kaili's expansion into Buol had another target, while the distance between Buol and Palu valley was so great. It was assumed that gold was known by them before Portuguese's coming. Kaili's expansion into Buol had another target, while the distance between Buol and Palu valley was so great. It was assumed that Buol's gold was known before Portuguese's coming.

In 1680 Gorontalo and Limboto that Islamized, reduced Buols's influence and attracted most of Buol's prosperity to move to Lewas, located between Buol and Kaidipang. Islam used as a main way to annex Buol. However, Buol's people, also Islamized, did not understand it. According to A Rahim Samad, Buol was Islamized after her king's conversion in Ternate. [5]

Buol was a kampong under a jogugu named Balamagile. To prevent Gorontalo's hegemony that recruiting Buol's people as a slave, Buol's ruler made a contact with the Dutch Company's governor in Ternate. Governor Robert Padtbrugge ordered in 1705 that Buol was under control of the Company, that ruled by Jan Blaauw as her official. Her motivation was a fact that Buol had a potential natrural source, especially iron and lingua wood that suitable for making ship, house and fortification. Buol was connected to hinterland of Central Sulawesi and Gorontalo over some waterways. Gorontalo's rapid economic growth in the middle of nineteenth century motivated Buol to make an active interaction more to Gorontalo than to Central Sulawesi. [6]

Gorontalo's influence expanded slowly to Buol's hinterland and more Gorontalo people came to Buol. Islam had a great impact, even Gorontalo's culture and language dominated Buol's local culture. [7] Before it, Buol's domination was so great [8], that her first king was installed in Ternate. A Rahim Samad says that:

Sultan Eato was converted into Islam following his father. It was assumed that title of Sultan was provided for his installation in Ternate. It was proved by giving a royal scepter, that known as Botango Raja in Buol's vernacular, with a Sultan of Ternate's initial on its top. [9]

Under Sultan Eato's rule, Muhammad Tahir (15601592), Ternate's influence was so dominant in Buol, because Sultanate of Ternate established Islam as a law of the state under Sultan Zainal Abidin (1468-1500). It was happening after the Sultan had returned from Gresik, as he learnt to Sunan Gore in 1495 and after his returning, he made a structural, institutional and judicial change. [10] According to Achdiati Ikram deck, "Islam was an ideological foundation of the social and political structure in a kingdom of button that imported from Ternate, at least twice namely in 1540 and 1580. [11]" But with Ternate's decline, her vassals that dominated by Sultan Baabullah, broke away. One of them was Buol. However, Ternate's influence was so great, that the Dutch needed Gorontalo's support for expanding into Buol in the middle of nineteenth century.
Gorontalo's rapid increasing influence at the time was backed up by the colonial new administrative system established in 1864. Based on it, Gorontalo was divided into two areas: self-control land (zelfbestuur) and government's land. Colonial rule dominated over Kwanand and Paguat, two areas with their strong economic basic. Kwandang was projected into a main port for Gorontalo, with the ocean shipping. Meanwhile, Paguat was known as a gold mining area. It had a strategic location because of a main landway between Gorontalo and Kotamobagu. Based on this division, a colonial official (controller) was placed in Kwandang and Paguat. Kwandang was an Onderafdeeling that controlling Kwandang, Atingola, Buol, Kaidipang, Bolaang Itam, Bintauna, and Bolaang Oki. [12] The administrative connection opened a chance for colonial and Gorontalo's local elite's intervention into Buol. It realized a colonial hegemony over local region. If Buol was seen as a local ruler, Gorontalo had a same status to colonial power with her capability to pressure Buol for subordinating to Batavia.

As Buol's political domination was established in Gorontalo, it was trying to realize in Boalemo, in 1875. Mansyur Syarif Ali, son of Syarif Ali, Buol's ruler with his Arabic origins, known as a virtuous figure, tried to motivate Boalemo's people for refusing Gorontalo's elite domination and subordinating to Buol. Knowing this, king of Gorontalo reported to assistant residents of Gorontalo. Based on the rapport, the Dutch resident in Menado ordered Mansyur to call back his father and forbade Boalemo to subordinate toward Buol. [13]

The Dutch strategy to subdue Syarif Mansyur over his father Syarif Ali was not a new one. She has applied the strategy since the sixteenth century. It was a colonial characteristic policy, namely devide et impera while the person did not feel it. Therefore, Syarif Ali did not feel as a victim of a colonial power that established in Gorontalo. For a while, Buol's ruler subordinated to the Dutch resident's instruction for losing a contact with Gorontalo. Three years later, as the king of Gorontalo Zainal Abidin al Habsyi Monoarfa died in April 1878, Mansyur provoked Buol's people of Ketanan for refusing any tribute to Gorontalo. Backed up by Bugis and Mandar pirates, Mansyur promised to protect them against Gorontalo. [14] Since the seventeenth century, the Bugis and Mandar pirates had never got a political position in Buol.

Jogugu as a representative of Gorontalo's king, had no authority to solve the problem, and he submitted to Gorontalo's assistant resident D. F. M. de Meyer. Meyer warned Mansyur to hold himself and to stop his activity. Meyer, knowing that behind Buol was Syarif Ali, pressed that sons of Buol's ruler's brother, Syarif Mohamad and Syarif Mangho, who living in Kotamobagu, were under supervision. [15] Syarif Mansyur was called to Menado by residents. Meyer's attitude with his ultimatum showed that the Dutch had no great power to act toward Syarif Mansyur. Her existence was supported by local rulers as a concept of stranger king - the inviting colonialism showing that the Dutch was invited by local rulers for solving their problem. Her coming was not free, but with a promise of a gift in a form of land cession. [16] Climax of colonial's intervention toward Buol was a new administrative structure after abolition of limo lo pohalaa, announced in Gorontalo on 6 July 1889, by Assistant 
Resident G. W. W. C. Baron van Hoevell for all native rulers of Gorontalo and Buol. Gorontalo was an afdeeling, consisted of some Onderafdeeling. Thus, Buol for the first time got a status as a modern governmental unit called as onderafdeeling under a controller. [17] The assignment of a controller marked a power reduction of the local ruler. The Dutch forced on Buol's king for her will because the king was seen as a lower official in the colonial structure.

Southern of Buol is Tolitoli, that since the early eighteenth century was known as a piratical nest with Makkasar Strait as their operational region. However, it was not limited to the water area. It was included a shore and fisher settlement. They were recruited to sell as a slave. [18] Its fame as a piratical nest was motivated by Sultan of Tolitoli's role as their protector. As said by J. Hunt, British commissaries for the Outside in 1812, that Tontoli is a great piratical establishment, governed by Sultan Muhammad Kubu. [19] Most pirates were not original people, but migrants of Southern Sulawesi, especially the Bugis. Thus, it was assumed that Tolitoli's ruler was a Bugis's descent, or at least the Bugis community had a great influence there. Until the late nineteenth century, the Dutch had a political connection to the local ruler of Tolitoli and the Bugis in Southern Sulawesi. [20] The Bugis domination made a great distance between Tolitoli and Buol, that dominated by Gorontalo. In the sixteenth and seventeen centuries, as Ternate's influence declined, the connection between Tolitoli and Buol was not so close to the nineteenth century. To the early twentieth century, Tolitoli had a more character of Bugis and Kaili than Buol, with the Gorontalo dominant character. [21]

A fact that Tolitoli had a Kaili character must be reviewed, because based on colonial classification of Central Sulawesi, she grouped them as an Alfuru. Mountain people in Tolitoli was not same in Kaili. According to Himmelman, the statement is rejected. [22] Linguistically, Tolitoli had no a vernacular of Kaili's family.

Buol is in the border between two cultural spheres, Gorontalo in northern and Bugis in Tolitoli. Gorontalo's culture is so dominant, but Buol's culture is still hold by her people. Gorontalo's cultural influence increased after Buol had been integrated into this region, as afdeeling Gorontalo was installed. Through Islam propaganda, Buol was subdued. However, Gorontalo was never come in political structure of Buol traditional. It differed from Kaili and Mangindanao. They were integrated into local political structure of Buol. It motivated Buol to approach Palu more than Gorontalo. Thus, Gorontalo could not establish her influence completely and permanently on Buol since the middle of nineteenth century. Any simple factor was a fact that Gorontalo's influence in Buol imposed a colonial "invisible hand", so that it failed to change a structural social foundation of Buol radically.

\section{Mine CONCESSION IN BUOL}

Global economic development in the late nineteenth century had motivated many countries, especially industrial based states as Netherland, with her industry as prime foundation for her system politically as well as economically. The Dutch's domination over all natural sources strengthened her position in international market for raw materials and industrial products, with their strategic value in international economic competition. [23]

The abolishing of Cultuurstelsel in Java of 1870s and its replacing with privatization of business in the Dutch East India colony had a great impact on the mother country's economy. [24] The privatization had been launched in Java and Sumatra, but in Sulawesi and particularly in Residency of Manado, a Cultuurstelsel-like managed exploitation system was applied so wide that there were many plantations and concessions in this region. After plantation, some concession for mining (gold, tin, and nickel) come in the early twentieth century. The Dutch tried to realize her idea for controlling all mineral sources.

However, the Dutch faced a reality that most material raw for industry or minerals were located in some areas that not under her control. Especially for minerals outside Java, until the middle of the nineteenth century, most of them were free states. Even some of them were ruled by a free ruler (zelfbestuur), while the rest had a traditional ruling system and owning pattern on their natural assets. [25]

A push of the capitalist power with her dominant influence in Dutch parliament since 1870, motivated the Dutch colonial government to subdue the region with her mineral sources under her control. Thus, pacification over outside Java was launched extensively in the last quarter of the nineteenth century. Some regions were persuaded to assume and to respect the Dutch control peacefully, over diplomatic way by politicians and anthropologist that sent from Batavia to discuss with native rulers. As this way failed, military expedition was an alternative for the sake of subordination. Diplomatic and military ways had one target: any political contract that guarantees the Dutch control.

Recognition of power was proved by any appointment of an official and a real integration into the colonial administrative territory. [26] By this way, the Dutch began to apply or even to increase her control over traditional bureaucracy, with guaranteed their traditional position. They also had a right for loon of colonial government. Traditional elite changed to be a colonial elite corps with rational legal in their thinking. [27] This bureaucracy was known as procedural bureaucracy, because they worked with a detailed and long procedural pattern.

Until the early twentieth century, the Dutch controlled all regions with a rich natural and mineral source, and exploited them for the sake of colonial interest. The research's result that made by the Dutch expert showed that Buol had a strategic and marketable potential mineral source. Therefore, two mining experts were sent to do any research. The process was possible with a political step of Batavia that abolishing Limo La Pohalaa (five political and traditional powers) that dominated by Gorontalo and Limboto in 1889, and opened a way for colonial arches toward Buol. [28] This step made the Dutch as an intermediary for solving some problems in Gorontalo and she could regulate traditional elite of Gorontalo and Limboto for pressure toward Buol, for the sake of its pacification.

In the early 1890, two Dutch geologists, namely P. Juginger and Goeseling, who assigned in Pajongo island, made a research in Buol. Their result proved that Buol's 
soil contained a rich gold and metal mine for exploration. The problem was a fact that the area was still under the control of free native ruler that guaranteed by the government. It motivated the Dutch to make an agreement with Buol's ruler for a further research over the mineral containment. [29] First step was taken to a research over Buol's natural condition for defining any further policy, exploration. Each exploration basically would ignore the local people. This was clear after a third party made any exploration after getting a concession from local ruler, like Buol.

As a further step, both report to their director, L. P. Dekker, in Priangan. After studying the result and its potential accurately, Dekker decided to offer a permission to the government for any discussion with Buol's ruler to explore his soil. Resident of Manado as a local authority provided a recommendation and Batavia considered Dekker's proposal in December 1890. [30] It was a proof that the legal rational pattern did well, and the Dutch colonial government determined all.

The good news was spread rapidly among investors and mining businessman in Batavia. A half year later, in August 1891, Firm P. Landberg en Zoon in Batavia proposed any recommendation to the government for any mining exploration in Buol. [31] This exploration by the Landberg spread of such news on gold mining in the north peninsula of Sulawesi, not only limited to Buol but also in the region from Gorontalo to Bolaang Mongondo. [32]

Batavia took an assertiveness as many proposals for exploration in northern Sulawesi came in. In the early November 1891, the government rejected all proposals with a reason it was unripe for it. [33] To assert this rejection, the Dutch pressed Buol's ruler to sign a political contract with her. Over this contract, the Dutch forbad Buol's ruler to waive his right to some private companies for mining exploitation. This contract changed a decision that published on 13 December 1890 related to exploitation permit of meaning that legalized in March 1892. [34] Through intensive lobby, Firm Landberg in Batavia convinced the government about the important value of mining exploration in Buol. The firm's director proposed a proof that in Paleleh gulf, it was found any colloidal gold, silver and tin source. Given that Firm Landberg had exploited a great gold mine in Panasakan and Totok, Minahasa, and also any fears toward Australian activities in gold mining around Sumalata (Gorontalo), resident of Manado proposed to Batavia any exploitation permit over gold mine for this firm around Paleleh gulf, begun the late October 1892. [35] To realize that, Firm Landberg formed a branch named as Nederlandsch Indische Mijnbouw Maatschappij. Based on Government decision 9 October 1892, a permit was provided for any research and exploitation of gold mine in Buol, and determined any location as a concession area for five years. [36] In the five years' research, decision for a mining concession over Paleleh would be made.

Batavia's step to provide any permit for Firm Landberg invited some protest of investors and they accused that the government acted discriminatively. They sent a formal protest letter to the Dutch parliament in Den Haag. In this letter, it was said that because of political consideration, the Dutch colonial government involved some Buol's royal families in Paleleh mining exploration and Firm Landberg got any priorities. [37] But the protest failed, so that there was any interruption in parliamentary Plano as Minister of Colony read Koloniaal Verslag in June 1893

The result of exploration showed any potential metal containment in Paleleh's soil that being ripe for exploitation. It motivated some companies to invest with any proposal to the government, as NV. Nederlandsch Indische Mijnbouwmaatschappij. [38] This company made any contact with Buol's ruler and stated that she would propose any permit for concession over Paleleh's soil to the Dutch. However, such permit was provided to Firm Landberg's branch, namely NV. Mijnbouw Maatschappij Paleleh located in Batavia, on 29 June 1897. [39] The concession was made for seventy-five years and involved a region around Paleleh's estuary with a wide 21.289 hectare.

The objects of exploitation in this concession were gold, silver, copper, brass, nickel and iron ore. With such concession, the company's share increased rapidly to $200 \%$. It was caused by a good prospect of potential metal exploitation and proved its high price value of the mineral. [40] Until December 1897, a sale of share by this company reached values of 600.000 , less than a half of the rest. [41] From the start - as the research was made by a Dutch company - to exploration phase of mineral source in Buol, there were three major problems to be solved: 1) Buol's ruler could not control his state; 2) the Dutch needed not Gorontalo as a partner in mine concession; and 3) Buol's rich soil was the Dutch property.

At the time, Buol was ruled by King Muhammad Soradjuddin with title Ta Meeraji. He, later known as Turubwou but changed into Turungku by the Dutch, was a Buol's ruler who signed Lange Verklaring (long contract) on 31 August 1964. [42] Since the time, Buol people paid a tax to the government. It was a proof that Buol traditional elite could not rise against the colonial pressure. Possibly they were angry, but could do nothing because de facto and the de jure bowl was a part of the Dutch East India. Her ruler and traditional elite were trapped between two interests, namely people's interest for freedom in the one hand and interest in mineral source exploitation by the Dutch in the other hand.

After the signing of Lange Verklaring between Buol and the Dutch, Gorontalo's economic and political influence held in Buol. But they had no political access anymore. The access was taken over by the Dutch and it was the Dutch target to manage Buol and Gorontalo as a part of the Manado Residency. It prevented Gorontalo to change buss' new political structure. However, Gorontalo maintained herself as Buol's economic and cultural partner, especially because of Islam. A unique historical project appeared, because Gorontalo was superior but not dominant, and socially as well as politically, Buol could defend herself. All of these were made by the Dutch with an administrative border to regulate both. Buol and Gorontalo never understood that the Dutch would control Paleleh forever. Moreover, Paleleh was not integrated into one of Buol's balaks. [43]

In the late nineteenth century, after thirty years' effort, the Dutch controlled Paleleh successfully. Mine concession was provided to a Dutch firm, namely Lamberg. Paleleh's mineral containment with her high price economy was exploited in 1896. Buol people got 
nothing but any hatred against their ruler, included the Dutch. At such situation was never seen by Buol traditional elite, under the Dutch and under the national government of Indonesia, namely a latent hatred feeling among Buol and Paleleh people. [44] It will be broken as a serious problem if it is failed to solve. The main cause is any mistake of policy to manage Buol's soil by outsiders.

\section{STRUCTURAL CHANGE}

Activity in the mining sector in the last decade of nineteenth century motivated any increase in Europeans visit to this colony. It supported the colonial government for establishing a tighter control over Buol to prevent any riot that harming public, government and local elite. Thus, the government promoted an official in Buol with an administrative authority. In place of assistant resident in Gorontalo, since July 1893 Buol was under a class-1 controller in a bowl. This official subordinated to resident in Manado directly, not to assistant resident in Gorontalo. [45] His task was to protect European, government's interest and native people against any pressure, and to supervise political contract's application, and relation between native elite and private persons. [46]

A successful exploitation of Paleleh's mineral mining with a high price production in Europe market had a great impact on this area. Only some months since a first product sending to Europe and the publish of result for the firm's directors as concession holder, Ir. Vermes was ordered by the directors to plan a complex building with all supporting infrastructure, included railways that connected Paleleh and port of Kwandang. [47] Although all were built for the sake of the company, the government felt that any social change would be born as a result and any supervision and intervention was necessary.

A doubtful attitude of Buol's ruler aroused any suspicion among the Dutch officials in North Sulawesi. They assumed that he did not like any intervention of the Dutch of any exploitative company in his area. It was proved by any riot in Paleleh mining complex in April 1901, triggered by any gold stealing and some labors were accused to do it. As a result, a mandor of Gorontalo fallen as a victim. [48]

After forty years under the colonial control and trapped between two interests, Buol's ruler began to take an opposition against the Dutch. It did not get a serious attention, because at the time situation in Sulawesi was in danger in relation with any war between the Dutch and Bone. At the end of September 1904, any lease for rattan and Sagoo harvest to private meant any violation against the government's monopoly that guaranteed by contract. Therefore, controller in Paleleh sent an ultimatum with his temple, but it was ignored by local rulers. [49] The opposition was aroused by any feeling that Buol people did not get any product of their soil. Buol's ruler at that time, Datu Alam Turungku, started to make any political conspiracy as mentioned above. Moreover, the colonial corps that established in Buol had a task only to protect Europeans and their business interest.

The above mentioned dynamics forced any consideration among colonial politicians in Batavia to see that controller in Paleleh was not suitable anymore. The area had to be under a civil gezaghebber, namely an active military officer as a chief of local government. To this officer, the area was stated as an emergency. By the end of 1906, a such change of position was made in buol after any change in bureaucracy of Gorontalo that abolishing controller in Sumalata. [50]

Because the colonial regime needed any reorganization of administrative and new division territory, that released in 1908, position of civil gezaghebber in Buol was maintained. This official in Paleleh finished the authority of Buol's ruler practically in ruling his state and he got an absolute authority as the Dutch representative there. [51] However, a great administrative change was made in April 1911, as the Dutch government created Afdeeling Midden Celebes under an Assistant Resident in Donggala. [52] In this new administrative structure, Buol had not yet been integrated into Afdeeling Midden Celebes, still as a part of Afdeeling Gorontalo. But the colonial approach toward Buol from Central Sulawesi start to realize, technically and politically.

The Dutch considered that it was better to control Buol from Donggala than Gorontalo, as a potential area for mining. Politically, it was meant to weaken Gorontalo's position because of Buol integration and to open a way for the government's control over gold mining there. Strategically, Buol was taken at a location to establish peace and order in that region, especially to protect the area in Makassar Strait against the pirates. Therefore, in January 1912, a unit of meshes under Captain Boonstra van Herdt was instructed to move along the shore from Palu to Buol for strategic geographic mapping. [53]

In the above region, consequently the colonial regulation was applied and all authorities of Buol zelfbestuur were taken over by the Dutch. Among them were tax collection or products of the soil and heerendiensten (compulsory work) for the government, that devoted to the native ruler before. In this transition phase, some people made of a chance for their own interest. They collected illegal tax, at the same time with any tax increase and heerendiensten from the government. It motivated any reaction, especially in village Kontanan, district Bonobungu. On 26 June 1913, people of the village that objected toward tax collection and heerendiensten, would not fulfill the order and rebelled against the government. [54]

Gezaghebber W. J. D. Van Andel asked Buol's ruler to pressure his people, but the ruler refused it because he had no more authority to act. Therefore, van Andel called 14 soldiers from Kwandang, and they came in Buol on 30 June 1913. With a corps in Buol, they downed the river with a barge to Paleleh. Furthermore, twelve soldiers were also sent from Gorontalo to support them.

After a consolidation in Paleleh, accompanied by Buol's ruler, the unit departed under van Andel to Kontanan. They did not see any resistance because local people showed a passive attitude. From the investigation not longer, some provocations were found and captured. They were brought to Paleleh for a legal court. Meanwhile, Buol's ruler was ordered to announce to his people that the order was re-established and they could work. [55]

In the investigation, not only provocative but head of village Kontonan was also punished because he was negligent in his job. Haji Abdul Kadir, an old man as head 
of the village, was so weak to control his people. Even, with villages Lantikadigo and Kodilagen around it, local people rejected to do heerendiensten since January 1913. As a result, the government dismissed Abdul Kadir from his post and replaced with a younger and more energetic one. [56]

Buol's ruler, Datu Alam Turungku, was also accused to be responsible on his position. Although on 26 May 1913 he got a rapport on people's resistance and any instruction from gezaghebber to act, he was failed to call them in Kontonan on 28 May 1913 for informing them about the replacement of head of village. Van Andel instructed marsaoleh of Paleleh, A. Baculu, to do it. Baculu managed to see local people and van Andel in Pokat, near Kontonan, on 16-17 June 1913. Even though the meeting in Pokat, that attended by Turungku, convinced the people on their compulsory, it could not prevent any rejection in Kontonan, Kodilagen and Lantikadigo, so that van Andel decided to act decisively.

Turungku's position was seen as a weak and the Dutch could not believe him for establishing peace and order, especially for their interest in Buol. Therefore, the government decided to reduce his authority and made him subordinate to her instruction. Based on it, in early September 1915, Governor General Idenburg agreed any taking over of tax and custom collection right from Turungku by gezaghebber of Buol. For realizing it, van Andel moved customs house from Leok to Buol. [57]

It was considered from the strategic view by the Dutch, namely to increase a maritime economic activity around Buol with Buol as a stopover place for great shipping. It was realized with a plan to build an ocean pier from the stones of village Tang in October 1917, with length 73 meters and a path in Tawa Eli Toboli. [58] This project was based on heerendiensten system and the local native ruler was instructed to mobilize his people without loon, for economic reason.

Since the time, Buol was in peace. As the riot was broken up again in village Salumpaga, near her border, in July 1919, [59] that involved Sarekat Islam branch in Tolitoli, the situation in Buol was conducive. Although SI had many followers there and some famous figures as Tjokroaminoto and Haji Samanhudi ordinate their care to Buol, SI's influence for two first decades in the twentieth century was limited and did not show any sign of resistance. [60]

The Dutch administrative structure was established, while the local traditional elite of Baal was eliminated and depended on their patron, the Dutch. Thus, to the end of the colonial regime, Buol was a part of Afdeeling Gorontalo. The condition changed in 1959 as Buol and Tolitoli Regency was made as a part of Central Sulawesi Province.

Each external power would provoke any political resistance, directly as well as indirectly. In Buol's condition, internal strength was a source of resistance, although the colonial regime in Batavia assumed them so weak. Case of Datu Alam Turungku as Buol's ruler and Haji Abdul Kadir as head of village Kontanan were proofs that some local agent could change a real structure, though they could not fight any external pressure. However, in the structure made by colonial in Buol and residency of Manado, there was a chance for a structural change. A reason for their failing was a dysfunction of pressure strength (Gorontalo), because of cultural and economic factors. But, internal effort in Buol continued to move for breaking the established colonial structure.

\section{SUMMARY}

In this part, it seems that Buol was integrated into two administrative units, namely Gorontalo in the past and then Central Sulawesi. At least, in her history, Buol has three periods: (1) in 1889, as the colonial administrative structure was established; (2) in 1959, as Buol and Tolitoli regency was announced, and (3) 1999 as Buol was separated from Tolitoli and established as a regency. Viewed from the period, Buol experienced any administrative change for every 40-50 years.

In two first period, 1889 and 1959, the external strength was dominant while in the last, 1999, internal strength played a significant role. With Gidden's conception, agency process is seen in the last period as an internal strength of bowel can break a dominant structure up in controlling social and political system. Furthermore, history of bowl between 1889 and 1919 shows that there are two phenomena that influencing this region's development, namely her natural source and two cultural living styles in border territory, Gorontalo and Central Sulawesi. Both phenomena are integrated into a dominant political structure. With capital and power, Buol's natural source is exploited. With external power from above, Buol is forced to participate in a new structure that made by a dominant elite, colonized in the past and regional or national in the present.

Reaction of internal strength among Buol people cannot balance toward a structure, and it was realized under the Dutch structure. From common people to the political elite in Buol, they were under a tighter control of colonial in all aspects of life. Practically, there was no reaction to any change that made by the colonial, politically as well as economically.

\section{REFERENCES}

[1] Anthony Giddens, The Constitution of Society: Outline of the Theory of Structuration (Maiden, 2007, Polity Press), p. 162.

[2] A Rahim Samad, Sejarah Buol Jilid 1 (Palu: Perum PNRI, 2000) pp 33-34.

[3] Francois Valentijn, Oud en nieuws Oost-Indien, page 71. From the names, it is thinkable that Buol was under Spaniard's and Portuguese's influence. Thus, they were converted into Catholic, not Protestant Christian.

[4] A Rahim Samad Op.cit., p. 45-46.

[5] Ibid., p. 13.

[6] ANRI, Politiek verslag van residentie Manado over het jaar 1856 , bundle Menado number 48 .

[7] Staatsblad van Nederlandsch Indie 1864 number 128

[8] M. Adnan Amal, Kepulauan Rempah-Rempah: Perjalanan Sejarah Maluku Utara 1250-1950 (Jakarta: KPG dan Pemerintah Provinsi Maluku Utara, 2010), p. 64.

[9] A Rahim Samad, Op.cit., p. 35.

[10] Chapter four, Ternate: Kerajaan Maluku Terbesar in M. Adnan Amal, Kepulauan Rempah-Rempah: Perjalanan Sejarah Maluku Utara 1250-1950 (Jakarta: KPG dan Pemerintah Provinsi Maluku Utara, 2010), pp. 53-158.

[11] Achdiati Ikram, dkk, Katalog Naskah Buton: Koleksi Abdul Mulku Zahari (Jakarta: Mannasa, The Toyota Foundation, dan YOI, 2001), pp. 2-3.

[12] Staatsblad van Nederlandsch Indie 1864 number 128 
[13] ANRI, Algemeen verslag van het Residentie Manado over het jaar 1875, bundle Menado number 52.

[14] ANRI, Algemeen verslag van het Residentie Manado over het jaar 1879, bundle Menado number 53

[15] "Indische Kroniek" dalam Sumatra Courant, tanggal 26 Februari 1876 , p. 2.

[16] Henley, Nationalism and Regionalism in a Colonial Context: Minahasa in the Ducth East Indies (Leiden:KITLV, 1996), p. 38.

[17] Staatsblad van Nederlandsch Indie, 1889 number. 94

[18] James Francis Warren, Ilanun and Balangingi: globalization, maritime raiding and the birth of ethnicity (Singapore, 2002, Singapore University Press), p. 155.

[19] James Francis Warren, The Sulu zone, 1768-1898: the dynamics of external trade, slavery and ethnicity in the transformation of a Southeast Asian Maritime State (Singapore, 2007, NUS Press), p. 164. According to Hunt, Tontoli was defended by 300 canons and 3000 Iranun or Ilanun pirates. It is possibly that the rapport was exaggerated because the number shows any interpretation and not as a right calculation.

[20] "Indische Kroniek" in Sumatra Courant, dated 27 October 1875, p. 2.

[21] David Henley, Fertility, Food and Fever: population, economy and environment in nirth and central Sulawesi 1600-1930 (Leiden, 2005, KITLV Press), page 217. The Bugis domination in Toli-Toli could be proved in 1930 as a population cencus showed that a third one of local people was the real Bugis, while the rest was a mixture descent of Bugis. Buol was often piratical target and slave recruitment by the Bugis pirate of Tolitoli to the late nineteenth century, while a slavery in Gorontalo was abolished in 1863.

[22] Nikolaus P. Himmelmann, "Language endangerment scenarios in northern Central Sulawesi", Artikel for the International Workshop on South-East Asian Studies No. 11: The study of endangered languages and literature of South-East Asiain Leiden in December 1996.

[23] H.W. van den Doel, Het rijk van Insulinde: opkomst en ondergang van een Nederlandsch kolonie (Amsterdam, Promotheus, 1996), p. 132

[24] van Zenden dan Daan Maarks, Ekonomi Indonesia 1800-2010: Antara Drama dan Keajaiban Pertumbuhan (Jakarta: Kompas dan KITLV-Jakarta, 2012), p. 162.

[25] Anoniem,"Bepalingen op het verkrijgen van gronden van vorsten of hoofden in den Indische Archipel, die nog het recht van zelfbestuur bezitten", in Tijdschrift voor Nederlandsch Indie, 1880, vol. II, p. 390

[26] J. Th. Lindblad, "De opkomst van de Buitengewesten" in A.H.P. Clemens en J.Th. Lindblad, Het belang van de buitengewesten: economische expansie en koloniale staatsvorming in de Buitengewesten van Nederlands Indie 1870-1942 (Amsterdam, 1989, NEHA), p. 3.

[27] Munawiah, Birokrasi Kolonial di Aceh 1903-1942 (Yogyakarta: Tesis FIB UGM, Tidak diterbitkan, 2002), p. 73.

[28] ANRI, Besluit van Gouverneur Generaal 17 April 1889 number 9 , bundle Algemeen Secretarie.

[29] "Nederlandsch Indie" in Java Bode, dated 6 October 1890, p. 2

[30] "Nederlandsch Indie" in Bataviaasch Nieuwsblad, dated 27 December 1890, p. 2.

[31] "Nederlandsch Indie" in Bataviaasch Nieuwsblad, 21 August 1891 , p. 2.

[32] "Nederlandsch Indie" in Bataviaasch Handelsblad, 16 October 1891 , p. 2.

[33] "Nederlandsch Indie" in Java Bode, 6 November 1891, p. 2.

[34] "Nederlandsch Indie", in De Locomotief, 8 March 1892, p. 2.

[35] “"Uit de Indische Bladen” in De Locomotief, 28 October 1892, p. 2.

[36] "Nederlandsch Indie" in Bataviaasch Nieuwsblad, 8 November 1892 , p. 2.

[37] "Nederlandsch Indie" in Soerajabasch Handelsblad, 24 December 1892 , p. 2.

[38] "Het bericht" in De Locomotief, 29 April 1897, p. 2.

[39] ANRI, Besluit van Gouverneur Generaal 29 Juni 1897 number. 19, bundle Algemeen Secretarie.

[40] "Bericht" in De Locomotief, 1 July 1897, p. 2.

[41] "Bericht" in Soerabajasch Handelsblad, 18 December 1897, p.1.
[42] A Rahim Samad, Op.cit., p. 69.

[43] Ibid, p. 69-70.

[44] Ibid.

[45] "Laaste berichten" in Bataviaasch Nieuwsblad, 19 July 1893, p. 2.

[46] "Particulier" in Soerabajasch Handelsblad, 25 October 1893 , page. 2. For example, as a Dutch name Burlage made a contract with Buol's ruler for ground rent secretly, controleur prevented sooner and proposed to the resident to cancel it

[47] "Nederlandsch Indie" in Bataviaasch Nieuwsblad, 4 December 1897 , p. 2.

[48] Koloniaal Verslag over het jaar 1901, p. 38.

[49] "Boni" in Het nieuws van den dag voor Nederlandsch Indie, 6 Okcober 1904, p. 2.

[50] "Bestuurorganisatie in Midden Celebes" in Bataviaasch Handelsblad, 28 September 1906, p. 2.

[51] ANRI, Besluit van Gouverneur Generaal 24 November 1908 number 48, bundle Algemeen Secretarie.

[52] ANRI, Besluit van Gouverneur Generaal 13 April 1911 no. 11, bundle Algemeen Secretarie.

[53] "Exploratie in Noord Celebes" in Het nieuws van den dag voor Nederlandsch Indie, 3 January 1912, p. 1.

[54] "Menado" in Het nieuws van den dag voor Nederlandesh Indie, 1 July 1913, p. 1.

[55] "Het einde van een opstootje" in Het nieuws van den dag voor Nederlandsch Indie, tanggal 8 July 1913, p. 2.

[56] "Korte verslag", in Bataviaasch Nieuwsblad, 24 October 1913, p. 3.

[57] "Een regeerings-daad" in Het nieuws van den dag voor Nederlandsch Indie, 11 September 1915, p. 2.

[58] "Uit Menado" in Bataviaasch Nieuwsblad, 17 December 1917, p.

[59] "De moord op den Controleur van Toli-Toli" in De Sumatra Pos, 3 July 1919, p. 2

[60] "De onrust in de Menadosche" in Bataviaasch Nieuwsblad, 18 September 1919, p. 2. 